\title{
Selective Laser Trabeculoplasty: A Clinical Review
}

\author{
${ }^{1}$ Skaat Alon
}

\begin{abstract}
Selective laser trabeculoplasty (SLT) is a safe and effective treatment modality for lowering the intraocular pressure in patients with glaucoma. It achieves its results by selective absorption of energy in the trabecular pigmented cells, sparing adjacent cells and tissues from thermal damage, with minimal morphological tissue alteration following treatment. On the basis of the peer-reviewed medical literature, SLT is efficacious in lowering IOP, as initial treatment or when medical therapy is insufficient in all types of open-angle glaucoma in all races. SLT achieves intraocular pressure reduction similar to that of argon laser trabeculoplasty but without the tissue destruction and side effects. Observed side effects following SLT were almost uniformly transient and minor. We review highlights of recently published studies on the mechanisms and clinical outcome of $\mathrm{SLT}$ in order to address frequently raised issues pertinent to SLT in the clinical practice.
\end{abstract}

Keywords: Selective laser trabeculoplasty, Glaucoma, Trabecular meshwork.

Key messages: Selective laser trabeculoplasty is a safe and effective treatment modality for lowering the intraocular pressure in patients with glaucoma.

How to cite this article: Alon S. Selective Laser Trabeculoplasty: A Clinical Review. J Current Glau Prac 2013; 7(2):58-65.

\section{Source of support: Nil}

Conflict of interest: None declared

\section{INTRODUCTION}

Lowering the patient's intraocular pressure (IOP) is the mainstay of glaucoma treatment, in an attempt to arrest the characteristic progressive optic neuropathy and prevent irreversible visual field loss. ${ }^{1}$ This goal may be achieved either by medical, laser or surgical modalities.

Laser trabeculoplasty (LTP) has been used to lower IOP for 40 years, following the landmark publication of Wise and Witter. ${ }^{2}$ This procedure was originally performed using the then-common argon laser (major laser wavelengths at 488 and $514 \mathrm{~nm}$ ), and so termed argon laser trabeculoplasty (ALT).

Several other lasers, including krypton (647.1 or $568.2 \mathrm{~nm}),{ }^{3}$ diode $(810 \mathrm{~nm}),{ }^{4}$ and frequency-doubled $\mathrm{Nd}$ :YAG $(532 \mathrm{~nm}),{ }^{5}$ at similar radiation parameters, have been described to yield a reduction of IOP similar to that of ALT. Several advantages characterize LTP, of which, first and foremost, is its ability to lower IOP without relying on patient compliance. Poor patient compliance has been repeatedly shown to be a key challenge in glaucoma medical treatment. There are a myriad of adherence barriers inherent to the glaucoma patient population, such as older age, medication cost, complicated dosing regimens and poor eye drop instillation technique. ${ }^{6-10}$ Noncompliance is especially significant when patients use more than one medication ${ }^{11}$ and ultimately leads to suboptimal, inconsistent IOP control. By replacing or decreasing the need for topical medications, LTP can improve IOP control, reduce systemic side effects such as cardiovascular and respiratory adverse events and depression ${ }^{12,13}$ and local side-effects, such as eyelid dermatitis, lacrimal system scarring, ocular discomfort upon instillation, tear film instability, subconjunctival fibrosis, conjunctival inflammation and epithelium changes and corneal surface and endothelial impairment. ${ }^{14}$

Moreover, by avoiding or delaying the need for filtration surgery, LTP can prevent the numerous and well-recognized associated short-term complications such as hypotony, shallow anterior chamber, bleb leak, and choroidal detachment, as well as long-term complications, such as progression of cataract and life-long risk of endophthalmitis. ${ }^{15,16}$

From the financial perspective, LTP seems to be a more cost-effective alternative. ${ }^{17}$

\section{What is Selective Laser Trabeculoplasty?}

In 1983 Anderson and Parrish ${ }^{18}$ discovered that selectively absorbed optical radiation could cause damage (photothermolysis) to a selected pigmented cell population within a tissue composed of multiple cell types. This selective photothermolysis theory, which was first applied in dermatology, made precise aiming unnecessary because the inherent properties of the tissue provided target selectivity. Selective laser trabeculoplasty (SLT) is based on this concept and is possible because pigmented trabecular meshwork (TM) cells exhibit greater optical absorbance of the applied laser energy than the cells that surround them. Therefore, a short burst of laser energy heats and thermally damages pigmented TM cells before neighboring cells have a chance to absorb enough laser energy to incur any thermal damage, ${ }^{19}$ as demonstrated by Latina and Park. ${ }^{20}$

SLT was approved by the FDA in 2002. It uses a $532 \mathrm{~nm}$ Q-switched, frequency-doubled Nd:YAG laser which is able to deliver a short pulse of $3 \mathrm{~ns}$ duration that limits the conversion of energy to heat. Transmission electron microscopy has demonstrated that SLT results in fracturing of melanin granules and rupturing of lysosomal membranes in the pigmented cells, with the absence of ultrastructural damage in neighboring nonpigmented cells. ${ }^{20,21}$ 


\section{MECHANISMS OF ACTION}

A number of theories have been proposed regarding the mechanism of LTP: ${ }^{22}$

The main theory attributed to SLT is biological, which suggesting that the decrease in IOP is the result of cellular activity stimulated by the laser energy. Following LTP, there is an increase in the recruitment and number of macrophages in the TM that cause remodeling of the extracellular matrix allowing increased aqueous outflow from the eye. ${ }^{23}$ Other publications ${ }^{24}$ have shown that LTP induces the expression and secretion of both IL-1beta and TNF alpha within the first 8 hours after treatment. These cytokines then mediate increased trabecular stromelysin expression. Putatively, this initiates remodeling of the juxtacanalicular extracellular matrix, a likely site for the aqueous outflow resistance, and thus improves normal outflow facility thereby decreasing IOP. Alvarado ${ }^{25}$ has shown that the number of monocytes/ macrophages in the TM increases substantially after SLT and monocytes augment both outflow facility and Schlemm canal endothelial cell conductivity. He also demonstrated ${ }^{26}$ that SLT, as do prostaglandin analogs (PA), regulates the permeability of cultured human Schlemm's canal cells by inducing intercellular junction disassembly. SLT caused a 3 -fold increase in Schlemm's canal cells conductivity which supports the hypothesis that SLT and PA share a common mechanism which mediates their pressure-lowering effects. It also emphasizes the role of intercellular junctions in regulating transendothelial fluid flow across Schlemm canal cells, which are assumed to be the last control point regulating the egress of aqueous humor from the intraocular fluid compartment into the venous compartment ${ }^{27}$ and therefore determining the IOP level. A histopathological study ${ }^{28}$ in human cadaver eyes demonstrated that while the appearance of the areas treated with ALT showed coagulative necrosis of the TM tissue, the areas treated with SLT demonstrated no such evidence of coagulative damage or disruption of the corneoscleral or uveal trabecular beam structure. Rather, it appears to cause cracking of the intracytoplasmic pigment granules and disruption of the trabecular endothelial cells. This study further supports the evidence that the mechanism of action of SLT is biological rather than mechanical.

\section{CLINICAL TECHNIQUE}

SLT uses a frequency doubled, q-switched Nd:YAG laser emitting at $532 \mathrm{~nm}$, with a pulse duration of $3 \mathrm{~ns}$, a spot size of $400 \mu \mathrm{m}$ and pulse energies ranging from 0.2 to $1.4 \mathrm{~mJ}$, coupled to a slit-lamp delivery system with a He-Ne aiming system.
Several protocols have been evaluated in an attempt to determine the SLT technique with the greatest efficacy. ${ }^{29}$ A comparison between the application of SLT over 90 and $180^{\circ}$ using 25 nonoverlapping laser spots per quadrant showed no difference in the pressure response between the two techniques. ${ }^{30}$ Other studies, however, demonstrated greater success rates with $180^{\circ}$ and $360^{\circ}$ treatments rather than with $90^{\circ}$ of SLT application ${ }^{31}$ and better results with $360^{\circ}$ SLT than with $180^{\circ}$ SLT. ${ }^{32}$ A modified protocol applying 100 overlapping SLT spots over $180^{\circ}$ of meshwork led to a poorer response compared with 100 nonoverlapping spots over $360^{\circ} .^{33}$

The treatment parameters and technique reported by most authors are the same or very similar to those originally described by Latina. ${ }^{34}$

Treatment with apraclonidine $1 \%$, an alpha-agonist, 1 hour before and just after the laser treatment might prevent a postoperative spike. ${ }^{35}$ Immediately prior to treatment, an application of topical anesthesia is instilled into the eye. The patient is seated at the slit-lamp, a single mirror Gonio lens is used, and the laser is focused on the pigmented TM. Using a $400 \mu \mathrm{m}$ spot (an area which is 64 times larger than that of the typical $50 \mu \mathrm{m}$ spot used in ALT) the entire width of the TM is irradiated with each pulse. The laser energy is initially set at $0.8 \mathrm{~mJ}$. If cavitation bubbles ('champagne bubbles') appear, the energy is reduced in $0.1 \mathrm{~mJ}$ increments until there is minimal or no bubble formation and treatment is continued at this energy level. If no cavitation bubbles occur, the energy is increased in increments of $0.1 \mathrm{~mJ}$ until bubble formation and then decreased as described above. The entire meshwork is treated with 100 nonoverlapping spots. Some ophthalmologists prefer to limit their initial treatment to $180^{\circ}$ due to clinical experience with ALT, after which a lower incidence of early IOP rise is known to occur compared with $360^{\circ}$ ALT. ${ }^{35}$ Others feel safer with SLT and therefore opt for a more effective procedure, treating $360^{\circ}$ in a single session. Postoperatively, steroidal or nonsteroidal anti-inflammatory drops may be prescribed four times a day for 5 to 7 days, although the role of suppressing post-SLT inflammation is unclear especially since, as mentioned previously, cytokine production has been theoretically linked to the IOP-lowering effect of SLT. ${ }^{36}$ Patients usually continue to take their preoperative glaucoma medications until the IOP is re-evaluated.

\section{INDICATIONS AND CONTRAINDICATIONS}

The indications for treatment with SLT are similar to that of ALT: ${ }^{37}$ (i) Newly diagnosed open angle glaucoma (OAG) patients; (ii) OAG patients uncontrolled on medical treatment; (iii) OAG patients with likely or actual poor 
compliance or poor tolerance to medical treatment; (iv) patients with pseudoexfoliation or pigmentary glaucomas.

It should be noted that IOP elevation after PKP was successfully treated with $\mathrm{SLT}^{38}$ which become a valuable therapeutic method that limits invasive surgery for treatment of secondary glaucoma after PKP.

Moreover, IOP elevation after intravitreal triamcinolone acetonide injection may be prevented by performing SLT before the injection ${ }^{39}$ or treated by SLT after the injection. ${ }^{40}$

Current contraindications include: (i) Inflammatory/ uveitic glaucoma, (ii) congenital glaucoma, (iii) poor visualization of the TM.

Contrary to previously held theory, Ho et $\mathrm{al}^{41}$ have shown that that IOP is effectively lowered by SLT in eyes with primary angle closure and a patent iridotomy in which there was a sufficient extent of visible TM.

\section{Worse, Better, Best-SLT in Comparison to Other Modalities}

Many comparisons have been made between SLT and other modalities in recent years.

One of the most interesting comparisons was between SLT and ALT.

The Cochrane Database Systematic review of $\mathrm{LTP}^{42,43}$ concluded in 2007 that there was some evidence to show similar efficacy in IOP control for SLT and ALT at 6 months and 1 year of follow-up. Since then, multiple retrospective ${ }^{44}$ and prospective ${ }^{45,46}$ clinical trials have been published and found no significant difference in IOP lowering when comparing SLT to $\mathrm{ALT}^{44,47,48}$ even over 5 years of follow-up. ${ }^{49}$ However, in retreatment SLT appears to lower IOP more effectively than ALT. ${ }^{47}$

Comparisons have also been made between SLT and medical treatment.

Comparing SLT with latanoprost, Nagar et al reported that SLT decreases pressure in a similar manner to latanoprost. However latanoprost was found to be more likely to reduce IOP fluctuation (success in fluctuation reduction was 50\% for SLT and 83\% for latanoprost), while SLT had the advantage of being a one-time intervention not requiring ongoing patient compliance. ${ }^{50}$

Comparisons between medication alone and a combination of SLT and medical treatment have shown an additional IOP reduction in patients uncontrolled with medical therapy who were treated with SLT. ${ }^{34,51-54}$ Francis et $\mathrm{al}^{55}$ and Klamann et $\mathrm{al}^{56}$ were able to reduce the number of glaucoma medications in most of their patients after SLT.

It is generally assumed that SLT treatment is equivalent in IOP lowering to the use of one drug. It must be noted, however, that as a proper dose-response relationship study has not yet been perfomed; it is possible that its effect can be improved.

\section{‘Not Destructive - Not Effective?'-SLT Effectiveness}

The first efficacy data for SLT was reported by Latina et $\mathrm{al}^{34}$ and demonstrated a mean IOP reduction of $6.0 \mathrm{~mm} \mathrm{Hg}$ ( $p<0.001)$ in eyes previously treated with ALT and 5.8 mm Hg ( $<$ 0.001) in eyes without prior ALT treatment. Overall, $70 \%$ of eyes exhibited an IOP reduction of $\geq 3 \mathrm{~mm} \mathrm{Hg}$.

Other prospective and retrospective studies ${ }^{52,57-63}$ have reported mean IOP reductions in the range of 3 to $6 \mathrm{~mm} \mathrm{Hg}$ from pretreatment baselines, equivalent to approximately 15 to $25 \%$ reduction from pretreatment IOP with the highest percentage reported being $35.9 \%{ }^{64}$ and the lowest $7.9 \% .{ }^{65}$

Studies ${ }^{45,46,65,66}$ which have compared the IOP-lowering efficacy of SLT and ALT concluded that SLT and ALT produce statistically equivalent mean IOP reductions, even after 5 years of follow-up. ${ }^{49}$

In a prospective randomized trial conducted by Lai et $\mathrm{al}^{53}$ mean IOP reduction after 5 years of follow-up was $8.6 \mathrm{~mm} \mathrm{Hg}$ (32.1\%) in SLT eyes and $8.7 \mathrm{~mm} \mathrm{Hg}$ (33.2\%) in medically treated eyes ( $\mathrm{p}=0.95)$. Treatment failure (IOP $>21 \mathrm{~mm}$ Hg despite maximal medical therapy requiring filtering surgery) in this study was observed in $17.2 \%$ of SLT eyes and $27.6 \%$ of medically treated eyes. Other studies $^{49}$ have reported higher failure rate (50\%) in a shorter time period ( 2 years). The wide range of success rates in various studies may be explained by the differences in study design and in the many factors which may affect the outcome of SLT including: ${ }^{62}$ glaucoma type, angle status, extent of angle treatment (180 vs 360 $)$, pretreatment IOP, number and type of medications and duration of medical treatment before SLT was performed.

SLT has been shown to be effective in almost all glaucoma types: POAG, ${ }^{42,62,63} \mathrm{OHT},{ }^{67} \mathrm{NTG},{ }^{68} \mathrm{PXF},{ }^{62,69-71}$ after cataract surgery, ${ }^{59}$ after intravitreal or subconjunctival triamcinolone, ${ }^{39,72}$ after failed deep sclerectomy, ${ }^{73}$ steroid induced glaucomas ${ }^{64,74}$ and elevated IOP after PKP. ${ }^{38}$

\section{SLT as Initial Therapy}

Nonrandomized, prospective studies by Melamed et $\mathrm{al}^{61}$ and McIlraith et $\mathrm{al}^{75}$ examined the use of SLT as initial therapy and reported IOP to be reduced by approximately 30\% compared to baseline levels, which is comparable with prostaglandin efficacy. ${ }^{76}$ Both trials noted a mean IOP reduction of $8 \mathrm{~mm} \mathrm{Hg}$.

A recent, prospective, randomized clinical trial, the SLT/ MED study, compared SLT with various medical treatment 
regimens as initial treatment and showed that the IOP reduction was similar in both arms after 1 year of follow-up. However, more treatment adjustment steps were needed to maintain target IOP in the medication group. ${ }^{77}$

\section{Baseline Factors Predictive of SLT Response}

In SLT, as in ALT, ${ }^{78}$ higher baseline IOP is almost the only baseline predictive factor of SLT response and found to be highly correlated with greater absolute IOP decrease. ${ }^{79-81}$ No significant differences in IOP response were found with regard to age, phakic status or gender. ${ }^{79}$

The presence of exfoliation, which was previously assumed to have an effect on IOP reduction, was found to have no such effect in 4 months follow-up post-SLT, but was significantly more prevalent in eyes that did not have retreatment, suggesting an association with increased success rate after SLT. ${ }^{30}$ Other publications showed that at 1 year follow-up after SLT, exfoliation glaucoma was not associated with a different outcome compared with $\mathrm{OAG}^{70,82,83}$

TM pigmentation, was also found in most of the studies $^{79,84,85}$ not to affect the success rate of SLT.

Race was also found to have no significant effect in the long-term success rates of SLT (especially with regard to African American and white patients). ${ }^{20}$ Also favorable results have been obtained with SLT in eyes of Asian descent. ${ }^{53,86-89}$

POAG and OHT patients treated with SLT as primary therapy who had thinner corneas $(\mathrm{CCT}<555 \mu \mathrm{m})$ demonstrated significantly greater percentage of IOP reduction and better IOP control for at least 30 months after SLT. ${ }^{90}$

In pseudophakic patients, SLT response was found to be delayed compared to phakic patients, while the longterm effectiveness (3 months and on) was the same in both groups. 59

Some reduction in effectiveness was reported in diabetic patients (only $1.2 \mathrm{~mm} \mathrm{Hg}$ IOP reduction) and in some reports IOP was even higher after SLT. ${ }^{62,91}$

\section{Adverse Effects of SLT}

The most common complication of SLT, as in ALT, ${ }^{92}$ is a transient rise in the IOP, which has been reported in $12 \%$ (>10 mm Hg) to $34 \%$ (>5 mm Hg) of patients. ${ }^{31,34,51,93,94}$ Generally, these spikes are not associated with any longterm effects and resolve quickly with observation or additional antihypertensive medications. ${ }^{36}$ They have been observed in almost all published series, whether or not the patients were receiving perioperative antihypertensive treatment. In one case series four eyes with a heavily pigmented TM developed markedly elevated IOP following SLT; three of which needed trabeculectomy. ${ }^{95}$

Transient anterior chamber reaction can result from SLT, albeit at a slightly lower rate than ALT. ${ }^{46}$ No significant increase in macular thickness was demonstrated due to this inflammatory reaction. ${ }^{56}$

Other possible side effects, such as redness, pain, and blurred vision, have also been described as transient and without sequelae in all studies.

Transient corneal endothelial changes that have no impact on cell count or visual acuity have also been reported. ${ }^{96}$

Rarely, corneal burns, significant peripheral anterior synechiae, reflux bleeding from the meshwork (Schlemm's) or hyphema have been noted ${ }^{45,97}$ and there is one report of bilateral diffuse lamellar keratitis following consecutive SLT in a LASIK patient. ${ }^{98}$

In summary, it can be said that complications due to SLT are infrequent and their effect is rarely permanent.

\section{SLT Advantages}

In addition to safety, efficacy and independence from compliance considerations, it seems that one of the main advantages of SLT is repeatability. Beneficial IOP reduction with SLT was reported in eyes that had been unresponsive to ALT ${ }^{94}$ Moreover, Hong et $\mathrm{al}^{99}$ demonstrated that in eyes which underwent an initial $360^{\circ}$ SLT (first SLT treatment) which was successful for more than 6 months, but eventually lost efficacy and was followed by a second $360^{\circ}$ SLT (second SLT treatment), both the first and second treatments significantly reduced the IOP with no significant difference in the efficacy outcomes between the first and second treatments.

Geyer et al ${ }^{100}$ have shown that one $180^{\circ}$ SLT treatment in 50 medically uncontrolled eyes facing incisional surgery succeeded in delaying surgery in $66 \%$ of the patients at 6 months and 55\% of the patients at 12 months; mean IOP reductions were 21 and $20 \%$ at 6 and 12 months respectively.

Moreover, as SLT is technically easier to perform compared with ALT, due to the less precise aiming required, it may be used by ophthalmologists with less experience in gonioscopy and angle surgery.

Cost analysis has shown that SLT is ultimately less expensive when compared with the costs of topical medications. ${ }^{101}$ SLT was found to be less costly than latanoprost after 13.1 months, ${ }^{101}$ more cost-effective than 75\% adherence PGs, and over 5 years SLT had the lowest total costs when compared to medication or to surgery ( $\mathrm{p}<$ 0.001). ${ }^{102}$ Taylor $^{103}$ has reported that initial laser trabeculoplasty followed by topical medication and then 
trabeculectomy was surprisingly cost-effective and was actually cost saving, returning $\$ 2.50$ for every $\$ 1.00$ spent, and even if the cost of laser treatment increased 4-fold, it still returned \$1.74 for each \$1.00 spent.

\section{SUMMARY}

SLT is a safe and effective procedure for reducing IOP. Although its mechanism of action is not fully understood, it provides short and long-term IOP reduction which is consistently equivalent to ALT.

SLT is effective at every stage in the glaucoma treatment algorithm and it may be used as first-line therapy, especially in noncompliant patients or patients who have difficulty taking drops. Similarly, SLT can be used effectively to reduce the number of medications required to control IOP, and can be used in eyes on maximal medical therapy to avoid or delay incisional surgery.

The procedure is easy to perform and well tolerated by patients. Some ophthalmologists prefer an initial treatment of $180^{\circ}$ due to previous clinical experience with ALT, but both $180^{\circ}$ and $360^{\circ}$ treatments have been well studied and both are successful as initial therapy. SLT, is nonmedical so eases concerns over adherence to side effects of, and costs of medical therapy. SLT therefore has a major role to play in the ophthalmologist's armamentarium for reducing IOP.

\section{REFERENCES}

1. The Advanced Glaucoma Intervention Study (AGIS): 7. The relationship between control of intraocular pressure and visual field deterioration. The AGIS Investigators. Am J Ophthalmol 2000 Oct;130(4):429-440.

2. Wise JB, Witter SL. Argon laser therapy for open-angle glaucoma. A pilot study. Arch Ophthalmol 1979 Feb;97(2):319322.

3. Spurny RC, Lederer CM Jr. Krypton laser trabeculoplasty. A clinical report. Arch Ophthalmol 1984 Nov;102(11):16261628.

4. Chung PY, Schuman JS, Netland PA, Lloyd-Muhammad RA, Jacobs DS. Five-year results of a randomized, prospective, clinical trial of diode vs argon laser trabeculoplasty for openangle glaucoma. Am J Ophthalmol 1998 Aug;126(2):185-190.

5. Guzey M, Arslan O, Tamcelik N, Satici A. Effects of frequency-doubled Nd:YAG laser trabeculoplasty on diurnal intraocular pressure variations in primary open-angle glaucoma. Ophthalmologica 1999;213(4):214-218.

6. Tsai JC. A comprehensive perspective on patient adherence to topical glaucoma therapy. Ophthalmology 2009 Nov;116(11 Suppl): 30S-36S.

7. Schwartz GF, Quigley HA. Adherence and persistence with glaucoma therapy. Surv Ophthalmol 2008 Nov;53 Suppl 1: 57S-68S.
8. Robin A, Grover DS. Compliance and adherence in glaucoma management. Indian J Ophthalmol 2011 Jan;59 Suppl:93S-96S.

9. Gupta R, Patil B, Shah BM, Bali SJ, Mishra SK, Dada T. Evaluating eye drop instillation technique in glaucoma patients. J Glaucoma 2012 Mar;21(3):189-192.

10. Sleath B, Blalock S, Covert D, Stone JL, Skinner AC, Muir K, Robin AL. The relationship between glaucoma medication adherence, eye drop technique and visual field defect severity. Ophthalmology 2011 Dec;118(12):2398-2402.

11. Robin AL, Covert D. Does adjunctive glaucoma therapy affect adherence to the initial primary therapy? Ophthalmology 2005 May;112(5):863-868.

12. Ergin A, Ornek K, Güllü R, Bulcun E, Ekici M, Ekici A. Effects of timolol and latanoprost on respiratory and cardiovascular status in elderly patients with glaucoma. J Ocul Pharmacol Ther 2009 Oct;25(5):463-466.

13. Han JA, Frishman WH, Wu Sun S, Palmiero PM, Petrillo R. Cardiovascular and respiratory considerations with pharmacotherapy of glaucoma and ocular hypertension. Cardiol Rev 2008 Mar-Apr;16(2):95-108.

14. Servat JJ, Bernardino CR. Effects of common topical antiglaucoma medications on the ocular surface, eyelids and periorbital tissue. Drugs Aging 2011 Apr;28(4):267-282.

15. Jampel HD, Solus JF, Tracey PA, Gilbert DL, Loyd TL, Jefferys JL, Quigley HA. Outcomes and bleb-related complications of trabeculectomy. Ophthalmology 2012 Apr;119(4):712-722.

16. Solus JF, Jampel HD, Tracey PA, Gilbert DL, Loyd TL, Jefferys JL, Quigley HA. Comparison of limbus-based and fornix-based trabeculectomy: success, bleb-related complications and bleb morphology. Ophthalmology 2012 Apr;119(4):703-711.

17. Stein JD, Kim DD, Peck WW, Giannetti SM, Hutton DW. Costeffectiveness of medications compared with laser trabeculoplasty in patients with newly diagnosed open-angle glaucoma. Arch Ophthalmol 2012 Apr;130(4):497-505.

18. Anderson RR, Parrish JA. Selective photothermolysis: precise microsurgery by selective absorption of pulsed radiation. Science 1983 Apr;220(4596):524-527.

19. Realini T. Selective laser trabeculoplasty: a review. J Glaucoma 2008 Sep;17(6):497-502.

20. Latina MA, Park C. Selective targeting of trabecular meshwork cells: in vitro studies of pulsed and CW laser interactions. Exp Eye Res 1995 Apr;60(4):359-371.

21. Holz HA, Lim MC. Glaucoma lasers: a review of the newer techniques. Curr Opin Ophthalmol 2005 Apr;16(2):89-93.

22. Stein JD, Challa P. Mechanisms of action and efficacy of argon laser trabeculoplasty and selective laser trabeculoplasty. Curr Opin Ophthalmol 2007 Mar;18(2):140-145.

23. Melamed S, Pei J, Epstein DL. Short-term effect of argon laser trabeculoplasty in monkeys. Arch Ophthalmol 1985 Oct;103(10):1546-1552.

24. Bradley JM, Anderssohn AM, Colvis CM, Parshley DE, Zhu XH, Ruddat MS, Samples JR, Acott TS. Mediation of laser trabeculoplasty-induced matrix metalloproteinase expression by IL-1beta and TNFalpha. Invest Ophthalmol Vis Sci 2000 Feb;41(2):422-430. 
25. Alvarado JA, Katz LJ, Trivedi S, Shifera AS. Monocyte modulation of aqueous outflow and recruitment to the trabecular meshwork following selective laser trabeculoplasty. Arch Ophthalmol 2010 Jun;128(6):731-737.

26. Alvarado JA, Iguchi R, Martinez J, Trivedi S, Shifera AS. Similar effects of selective laser trabeculoplasty and prostaglandin analogs on the permeability of cultured Schlemm canal cells. Am J Ophthalmol 2010 Aug;150(2):254-264.

27. Epstein DL, Rohen JW. Morphology of the trabecular meshwork and inner-wall endothelium after cationized ferritin perfusion in the monkey eye. Invest Ophthalmol Vis Sci 1991 Jan;32(1):160-171.

28. Kramer TR, Noecker RJ. Comparison of the morphologic changes after selective laser trabeculoplasty and argon laser trabeculoplasty in human eye bank eyes. Ophthalmology 2001 Apr;108(4):773-779.

29. Latina MA. Selective laser trabeculoplasty-180-degree treatment. J Glaucoma 2007 Mar;16(2):274-275.

30. Chen E, Golchin S, Blomdahl S. A comparison between 90 degrees and 180 degrees selective laser trabeculoplasty. J Glaucoma $2004 \mathrm{Feb}$;13(1):62-65.

31. Nagar M, Ogunyomade A, O’Brart DP, Howes F, Marshall J. A randomised, prospective study comparing selective laser trabeculoplasty with latanoprost for the control of intraocular pressure in ocular hypertension and open angle glaucoma. $\mathrm{Br}$ J Ophthalmol 2005 Nov;89(11):1413-1417.

32. Shibata M, Sugiyama T, Ishida O, Ueki M, Kojima S, Okuda $\mathrm{T}$, Ikeda T. Clinical results of selective laser trabeculoplasty in open-angle glaucoma in Japanese eyes: comparison of 180 degree with 360 degree SLT. J Glaucoma 2012 Jan;21(1):17-21.

33. George MK, Emerson JW, Cheema SA, McGlynn R, Ford BA, Martone JF, Shields MB, Wand M. Evaluation of a modified protocol for selective laser trabeculoplasty. J Glaucoma 2008 Apr-May;17(3):197-202.

34. Latina MA, Sibayan SA, Shin DH, Noecker RJ, Marcellino G. Q-switched 532-nm Nd:YAG laser trabeculoplasty (selective laser trabeculoplasty): a multicenter, pilot, clinical study. Ophthalmology 1998 Nov;105(11):2082-2090.

35. Allf BE, Shields MB. Early intraocular pressure response to laser trabeculoplasty 180 degrees without apraclonidine versus 360 degrees with apraclonidine. Ophthalmic Surg 1991 Sep;22(9):539-542.

36. Barkana Y, Belkin M. Selective laser trabeculoplasty. Surv Ophthalmol 2007 Nov-Dec;52(6):634-654.

37. Nagar, M. Selective laser trabeculoplasty. In: Garg A, Rosen E, editors. Instant clinical diagnosis in ophthalmology: Glaucoma. New Delhi: Jaypee Brothers Medical Publisher Ltd; 2009. p. 298-307.

38. Nakakura S, Imamura H, Nakamura T. Selective laser trabeculoplasty for glaucoma after penetrating keratoplasty. Optom Vis Sci 2009 Apr;86(4):e404-e406.

39. Bozkurt E, Kara N, Yazici AT, Yuksel K, Demirok A, Yilmaz OF, Demir S. Prophylactic selective laser trabeculoplasty in the prevention of intraocular pressure elevation after intravitreal triamcinolone acetonide injection. Am J Ophthalmol 2011 Dec;152(6):976-981.e2.

40. Baser E, Seymenoglu R. Selective laser trabeculoplasty for the treatment of intraocular pressure elevation after intravitreal triamcinolone injection. Can J Ophthalmol 2009 Jun;44(3).e21.

41. Ho CL, Lai JS, Aquino MV, Rojanapongpun P, Wong HT, Aquino MC, Gerber Y, Belkin M, Barkana Y. Selective laser trabeculoplasty for primary angle closure with persistently elevated intraocular pressure after iridotomy. J Glaucoma 2009 Sep;18(7):563-566.

42. Samples JR, Singh K, Lin SC, Francis BA, Hodapp E, Jampel HD, Smith SD. Laser trabeculoplasty for open-angle glaucoma: a report by the American academy of ophthalmology. Ophthalmology 2011 Nov;118(11):2296-2302.

43. Rolim de Moura C, Paranhos A Jr, Wormald R. Laser trabeculoplasty for open angle glaucoma. Cochrane Database Syst Rev 2007 Oct;17(4).

44. Juzych MS, Chopra V, Banitt MR, Hughes BA, Kim C, Goulas MT, Shin DH. Comparison of long-term outcomes of selective laser trabeculoplasty versus argon laser trabeculoplasty in openangle glaucoma. Ophthalmology 2004 Oct;111(10):1853-1859.

45. Damji KF, Bovell AM, Hodge WG, Rock W, Shah K, Buhrmann R, Pan YI. Selective laser trabeculoplasty versus argon laser trabeculoplasty: results from a 1-year randomised clinical trial. Br J Ophthalmol 2006 Dec; 90(12):1490-1494.

46. Martinez-de-la-Casa JM, Garcia-Feijoo J, Castillo A, Matilla M, Macias JM, Benitez-del-Castillo JM, Garcia-Sanchez J. Selective vs argon laser trabeculoplasty: hypotensive efficacy, anterior chamber inflammation and postoperative pain. Eye (Lond) 2004 May;18(5):498-502.

47. Russo V, Barone A, Cosma A, Stella A, Delle Noci N. Selective laser trabeculoplasty versus argon laser trabeculoplasty in patients with uncontrolled open-angle glaucoma. Eur J Ophthalmol 2009 May-Jun;19(3):429-434.

48. Liu Y, Birt CM. Argon versus selective laser trabeculoplasty in younger patients: 2-year results. J Glaucoma 2012 Feb;21(2):112-115.

49. Bovell AM, Damji KF, Hodge WG, Rock WJ, Buhrmann RR, Pan YI. Long-term effects on the lowering of intraocular pressure: selective laser or argon laser trabeculoplasty? Can J Ophthalmol 2011 Oct;46(5):408-413.

50. Nagar M, Luhishi E, Shah N. Intraocular pressure control and fluctuation: The effect of treatment with selective laser trabeculoplasty. Br J Ophthalmol 2009 Apr;93(4):497-501.

51. Gracner T. Intraocular pressure response to selective laser trabeculoplasty in the treatment of primary open-angle glaucoma. Ophthalmologica 2001 Jul-Aug;215(4):267-270.

52. Gracner T. Intraocular pressure response of capsular glaucoma and primary open-angle glaucoma to selective Nd:YAG laser trabeculoplasty: a prospective, comparative clinical trial. Eur J Ophthalmol 2002 Jul-Aug;12(4):287-292.

53. Lai JS, Chua JK, Tham CC, Lam DS. Five-year follow-up of selective laser trabeculoplasty in Chinese eyes. Clin Experiment Ophthalmol 2004 Aug;32(4):368-372.

54. Cvenkel B. One-year follow-up of selective laser trabeculoplasty in open-angle glaucoma. Ophthalmologica 2004 Jan-Feb;218(1):20-25.

55. Francis BA, Ianchulev T, Schofield JK, Minckler DS. Selective laser trabeculoplasty as a replacement for medical therapy in openangle glaucoma. Am J Ophthalmol 2005 Sep;140(3):524-525.

56. Klamann MK, Maier AK, Gonnermann J, Ruokonen PC. Adverse effects and short-term results after selective laser trabeculoplasty (SLT). J Glaucoma 2014 Feb;23(2):105-108.

57. Kajiya S, Hayakawa K, Sawaguchi S. Clinical results of selective laser trabeculoplasty. Jpn J Ophthalmol 2000 Sep;44(5):574-575.

58. Shazly TA, Latina MA. Intraocular pressure response to selective laser trabeculoplasty in the first treated eye vs the fellow eye. Arch Ophthalmol 2011 Jun;129(6):699-702. 
59. Shazly TA, Latina MA, Dagianis JJ, Chitturi S. Effect of prior cataract surgery on the long-term outcome of selective laser trabeculoplasty. Clin Ophthalmol 2011;5:377-380.

60. Gracner T, Falez M, Gracner B, Pahor D. Long-term followup of selective laser trabeculoplasty in primary open-angle glaucoma. Klin Monbl Augenheilkd 2006 Sep;223(9):743-747. (Ger).

61. Melamed S, Ben Simon GJ, Levkovitch-Verbin H. Selective laser trabeculoplasty as primary treatment for open-angle glaucoma: a prospective, nonrandomized pilot study. Arch Ophthalmol 2003 Jul;121(7):957-960.

62. Koucheki B, Hashemi H. Selective laser trabeculoplasty in the treatment of open-angle glaucoma. J Glaucoma 2012 Jan;21(1):65-70.

63. Thatsnarong D, Ngamchittiampai C, Phoksunthorn T. One year results of selective laser trabeculoplasty in the treatment of primary open angle glaucoma. J Med Assoc Thai 2010 Feb;93(2):211-214.

64. Tokuda N, Inoue J, Yamazaki I, Matsuzawa A, Munemasa Y, Kitaoka Y, Takagi H, Ueno S. Effects of selective laser trabeculoplasty treatment in steroid-induced glaucoma. Nihon Ganka Gakkai Zasshi 2012 Aug;116(8):751-757. (Jpn).

65. Best UP, Domack H, Schmidt V. Pressure reduction after selective laser trabeculoplasty with two different laser systems and after argon laser trabeculoplasty—a controlled prospective clinical trial on 284 eyes. Klin Monbl Augenheilkd 2007 Mar;224(3):173-179. (Ger).

66. Van de Veire S, Zeyen T, Stalmans I. Argon versus selective laser trabeculoplasty. Bull Soc Belge Ophtalmol 2006;(299): 5-10.

67. Beltran-Agullo L, Alaghband P, Obi A, Husain R, Lim KS. The effect of selective laser trabeculoplasty on aqueous humor dynamics in patients with ocular hypertension and primary open-angle glaucoma. J Glaucoma 2013 Dec;22(9):746-749.

68. El Mallah MK, Walsh MM, Stinnett SS, Asrani SG. Selective laser trabeculoplasty reduces mean IOP and IOP variation in normal tension glaucoma patients. Clin Ophthalmol 2010 Aug;4:889-893.

69. Goldenfeld M, Geyer O, Segev E, Kaplan-Messas A, Melamed S. Selective laser trabeculoplasty in uncontrolled pseudoexfoliation glaucoma. Ophthalmic Surg Lasers Imaging 2011 Sep-Oct;42(5):390-393.

70. Ayala M, Chen E. Comparison of selective laser trabeculoplasty (SLT) in primary open angle glaucoma and pseudoexfoliation glaucoma. Clin Ophthalmol 2011;5:1469-1473.

71. Shazly TA, Smith J, Latina MA. Long-term safety and efficacy of selective laser trabeculoplasty as primary therapy for the treatment of pseudoexfoliation glaucoma compared with primary open-angle glaucoma. Clin Ophthalmol 2010 Dec;5:5-10.

72. Yuki K, Inoue M, Shiba D, Kawamura R, Ishida S, Ohtake Y. Selective laser trabeculoplasty for elevated intraocular pressure following subtenon injection of triamcinolone acetonide. Clin Ophthalmol 2010 Apr;4:247-249.

73. Mansouri K, Mariani A, Ravinet E. Reconditioning of the trabeculo-descemet's membrane with the 532-nm Nd:YAG (SLT) laser after deep sclerectomy. Eye (Lond) 2011 Dec;25(12):1655-1657.
74. Rubin B, Taglienti A, Rothman RF, Marcus CH, Serle JB. The effect of selective laser trabeculoplasty on intraocular pressure in patients with intravitreal steroid-induced elevated intraocular pressure. J Glaucoma 2008 Jun-Jul;17(4):287-292.

75. McIlraith I, Strasfeld M, Colev G, Hutnik CM. Selective laser trabeculoplasty as initial and adjunctive treatment for openangle glaucoma. J Glaucoma 2006 Apr;15(2):124-130.

76. van der Valk R, Webers CA, Schouten JS, Zeegers MP, Hendrikse F, Prins MH. Intraocular pressure-lowering effects of all commonly used glaucoma drugs: a meta-analysis of randomized clinical trials. Ophthalmology 2005 Jul;112(7): 1177-1185.

77. Katz LJ, Steinmann WC, Kabir A, Molineaux J, Wizov SS, Marcellino G. Selective laser trabeculoplasty versus medical therapy as initial treatment of glaucoma: a prospective, randomized trial. J Glaucoma 2012 Sep;21(7):460-468.

78. Heijl A, Peters D, Leske MC, Bengtsson B. Effects of argon laser trabeculoplasty in the Early Manifest Glaucoma Trial. Am J Ophthalmol 2011 Nov;152(5):842-848.

79. Bruen R, Lesk MR, Harasymowycz P. Baseline factors predictive of SLT response: a prospective study. J Ophthalmol 2012;2012:1-5.

80. Tzimis V, Tze L, Ganesh J, Muhsen S, Kiss A, Kranemann C, Birt CM. Laser trabeculoplasty: an investigation into factors that might influence outcomes. Can J Ophthalmol 2011 Aug;46(4):305-309.

81. Johnson PB, Katz LJ, Rhee DJ. Selective laser trabeculoplasty: predictive value of early intraocular pressure measurements for success at 3 months. Br J Ophthalmol 2006 Jun;90(6):741-743.

82. Higginbotham EJ. Reaffirming the role of the laser in glaucoma management. Arch Ophthalmol 1999 Aug;117(8):1075-1076.

83. Song J, Lee PP, Epstein DL, Stinnett SS, Herndon LW Jr, Asrani SG, Allingham RR, Challa P. High failure rate associated with 180 degrees selective laser trabeculoplasty. J Glaucoma 2005 Oct;14(5):400-408.

84. Hodge WG, Damji KF, Rock W, Buhrmann R, Bovell AM, Pan Y. Baseline IOP predicts selective laser trabeculoplasty success at 1 year post-treatment: Results from a randomised clinical trial. Br J Ophthalmol 2005 Sep;89(9):1157-1160.

85. Weinreb RN, Ruderman J, Juster R, Zweig K. Immediate intraocular pressure response to argon laser trabeculoplasty. Am J Ophthalmol 1983 Mar;95(3):279-286.

86. Rasmussen CA, Kaufman PL. Primate glaucoma models. J Glaucoma 2005 Aug;14(4):311-314.

87. Tang M, Fu Y, Ma Y, Fu MS, Fan Y, Sun XD, Xu X. The efficacy of low-energy selective laser trabeculoplasty. Zhonghua Yan Ke Za Zhi 2011 Oct;47(10):887-892. (Chn).

88. Kano K, Kuwayama Y, Mizoue S, Ito N. Clinical results of selective laser trabeculoplasty. Nihon Ganka Gakkai Zasshi 1999 Aug;103(8):612-616. (Jpn).

89. Saito Y, Higashide T, Sugiyama K. Clinical results of selective laser trabeculoplasty as adjunctive treatment for primary openangle glaucoma patients. Nihon Ganka Gakkai Zasshi 2007 Dec;111(12):953-958. (Jpn).

90. Shazly TA, Latina MA, Dagianis JJ, Chitturi S. Effect of central corneal thickness on the long-term outcome of selective laser trabeculoplasty as primary treatment for ocular hypertension and primary open-angle glaucoma. Cornea 2012 Aug;31(8):883-886. 
91. Gracner T, Naji M, Hudovernik M, Gracner B, Pahor D. Predictive factors of successful selective laser trabeculoplasty in open-angle glaucoma. Klin Monbl Augenheilkd 2007 Dec;224(12):922-926. (Ger).

92. Greenfield DS, Liebmann JM, Ritch R. Brimonidine: a new alpha2adrenoreceptor agonist for glaucoma treatment. J Glaucoma 1997 Aug;6(4):250-258.

93. Glaucoma Laser Trial Research Group. The Glaucoma Laser Trial. I. Acute effects of argon laser trabeculoplasty on intraocular pressure. Arch Ophthalmol 1989 Aug;107(8):1135-1142.

94. Damji KF, Shah KC, Rock WJ, Bains HS, Hodge WG. Selective laser trabeculoplasty vs argon laser trabeculoplasty: a prospective randomised clinical trial. Br J Ophthalmol 1999 Jun;83(6):718-722.

95. Harasymowycz PJ, Papamatheakis DG, Latina M, De Leon M, Lesk MR, Damji KF. Selective laser trabeculoplasty (SLT) complicated by intraocular pressure elevation in eyes with heavily pigmented trabecular meshworks. Am J Ophthalmol 2005 Jun;139(6):1110-1113.

96. White AJ, Mukherjee A, Hanspal I, Sarkies NJ, Martin KR, Shah P. Acute transient corneal endothelial changes following selective laser trabeculoplasty. Clin Experiment Ophthalmol 2013 Jul;41(5):435-41.

97. Rhee DJ, Krad O, Pasquale LR. Hyphema following selective laser trabeculoplasty. Ophthalmic Surg Lasers Imaging 2009 SepOct;40(5):493-494.

98. Holz H, Pirouzian A. Bilateral diffuse lamellar keratitis following consecutive selective laser trabeculoplasty in LASIK patient. J Cataract Refract Surg 2010 May;36(5):847-849.
99. Hong BK, Winer JC, Martone JF, Wand M, Altman B, Shields B. Repeat selective laser trabeculoplasty. J Glaucoma 2009 Mar;18(3):180-183.

100. Geyer O, Wolf A, Levinger E, Orev T, Segev E. Selective laser trabeculoplasty treatment for medication-refractory open angle glaucoma. Harefuah 2005 Nov; 144(11):790-821. (Heb).

101. Seider MI, Keenan JD, Han Y. Cost of selective laser trabeculoplasty vs topical medications for glaucoma. Arch Ophthalmol 2012 Apr;130(4):529-530.

102. Cantor LB, Katz LJ, Cheng JW, Chen E, Tong KB, Peabody JW. Economic evaluation of medication, laser trabeculoplasty and filtering surgeries in treating patients with glaucoma in the US. Curr Med Res Opin 2008 Oct;24(10):2905-2918.

103. Taylor HR. Glaucoma: where to now? Ophthalmology 2009 May;116(5):821-822.

Goldschleger Eye Institute, Sheba Medical Center, Tel Aviv University, Tel Hashomer, Israel; Glaucoma Clinical Fellow, New York Eye and Ear Infirmary, New York, USA

Corresponding Author: Skaat Alon, Goldschleger Eye Institute Sheba Medical Center, Tel Aviv, University, Tel Hashomer, Israel; Glaucoma Clinical Fellow, New York Eye and Ear Infirmary, New York, USA, Phone: 972-35302874, Fax: 972-35302822, e-mail: skaatalon@gmail.com 